\title{
PERAN KARANG TARUNA DALAM SOSIALISASI PENCEGAHAN DAN PENANGGULANGAN PENULARAN COVID-19 DI LINGKUNGAN RW 011 KELURAHAN PENGASINAN, KOTA DEPOK
}

\author{
Herry Suherman, Kemas Vivi Andayani, Yulies Herni, Dijan Mardiati, \\ Selvy Dwi Widiyanti \\ Universitas Pamulang \\ Email: dosen01060@unpam.ac.id
}

\begin{abstract}
This Community Service aims to add insight and understanding of the Covid-19 virus and its transmission form through the activities of Youth Organisation RW.11 Pengasinan Village, Bogor. Youth Organisation as a social organization can provide examples of clean and healthy life behavior in order to prevent the transmission of Covid-19, which can be beneficial not only for the personal members of the Youth Organisation (in particular) but for the community (in general). The activity of devotion to the community carried out from 2 March 2020 to 10 July 2020 is done using methods of mentoring, counseling, practice and ever to explain comprehensively from the management side of a Covid-19 pandemic outbreak. The results of mentoring and counseling in the activities of community devotion is the experience and knowledge about the danger of Covid-19 to citizens of $R W 11$ environment through Youth Organisaton RW.11, Pengasinan, Bogor, West Java. In addition, through the activities of devotion to the community, handed over 60 basic food packages to the citizens affected by the Covid-19. The participants were enthusiastic and responded intelligently to the discussions presented. So with an increasing understanding of the dangers of Covid-19 in the Youth Organisation environment at $R W .11$, Pengasinan village, Depok, West Java.
\end{abstract}

Keywords: Community service, Youth Organization, Socialization of the dangers of Covid-19

\begin{abstract}
Abstrak
Pengabdian Kepada Masyarakat ini bertujuan untuk menambah wawasan dan pemahaman mengenai virus Covid-19 dan bentuk penularannya melalui kegiatan Karang taruna RW.11 Kelurahan Pengasinan, Bogor. Karang taruna sebagai organisasi sosial yang dapat memberikan contoh perilaku hidup bersih dan sehat agar mencegah penularan Covid-19, yangmana hal ini dapat dapat bermanfaat tidak hanya bagi pribadi anggota karang taruna sendiri (khususnya) namun bagi masyarakat (pada umumnya). Kegiatan Pengabdian Kepada Masyarakat yang dilaksanakan dari tanggal 2 Maret 2020 sampai dengan 10 Juli 2020 ini dilakukan dengan menggunakan metode pendampingan, penyuluhan, praktek dan pelatihan untuk menjelaskan secara komprehensif dari sisi manajemen mengenai penanggulangan wabah pandemic Covid-19. Hasil pendampingan dan
\end{abstract}


penyuluhan dalam kegiatan Pengabdian Kepada Masyarakat ini adalah adanya pengalaman dan pengetahuan mengenai bahaya Covid-19 kepada warga lingkungan RW.011 melalui kegiatan pemuda Karang Taruna RW 11, Pengasinan, Bogor, Jawa Barat. Selain itu melalui kegiatan Pengabdian kepada masyarakat ini, diserahkan bantuan 60 paket sembako kepada warga yang terdampak Covid-19. Peserta PKM sangat antusias dan menanggapi diskusi yang disajikan dengan cerdas. Sehingga dengan semakin bertambahnya pemahaman mengenai bahaya Covid-19 di lingkungan Karang Taruna RW.11, Pengasinan, Depok, Jawa Barat.

Kata Kunci: Pengabdian masyarakat, Karang Taruna, Sosialisasi bahaya Covid-19

\section{A. PENDAhULUAN}

Kasus virus corona di Indonesia terungkap usai ada laporan warga negara Jepang dinyatakan positif. Masalahnya, WN Jepang ini baru saja berkunjung ke Indonesia. Pemerintah kemudian langsung menelusuri siapa saja yang melakukan kontak dengan pasien tersebut. Pada tanggal 14 Februari 2020, pasien terinfeksi virus corona berdansa dengan WNA Jepang. Pasien berusia 31 tahun ini memang bekerja sebagai guru dansa dan WNA asal Jepang ini juga merupakan teman dekatnya. Selang dua hari, yakni 16 Februari 2020 pasien terkena sakit batuk.

Pasien kemudian melakukan pemeriksaan di rumah sakit terdekat. Namun, saat itu pasien langsung dibolehkan untuk kembali ke rumah atau rawat jalan. Sayang, sakit yang dideritanya tidak kunjung sembuh. Hingga pada 26 Februari 2020, pasien dirujuk lagi ke rumah sakit dan diminta untuk menjalani rawat inap. Pada saat itulah, batuk yang diderita pasien mulai disertai sesak napas. Mengetahui informasi tersebut, pihak rumah sakit langsung memasukkan pasien dalam status pemantauan terkait virus corona. Pada 28 Februari 2020, pasien mendapatkan telepon dari temannya yang di Malaysia. Dalam sambungan telepon tersebut, pasien mendapatkan informasi jika WNA Jepang yang merupakan temannya itu positif terinfeksi virus corona.

Pemerintah melalui Penanganan Virus Corona Indonesia menyampaikan informasi terbaru mengenai jumlah kasus dan data pasien Covid-19 hingga Sabtu, 11 Juli 2020 pukul 12.00 WIB menunjukkan, terdapat 1.671 kasus baru Covid-19 dalam 24 jam terakhir. Penambahan kasus baru itu menyebabkan kini ada 74.018 kasus Covid-19 di Indonesia, terhitung sejak diumumkannya pasien pertama oleh Presiden Joko Widodo pada 2 Maret 2020. Sebanyak 1.671 kasus baru ini didapatkan setelah dilakukan pemeriksaan 23.310 spesimen dari 12.265 orang dalam sehari. Total spesimen yang diperiksa kini mencapai 1.038.988 spesimen dari 610.093 orang. Dalam pemeriksaan spesimen, satu orang bisa diambil sampelnya lebih dari satu kali. Terkait persebaran, Yurianto menyebutkan lima provinsi dengan penambahan kasus Covid-19 terbanyak dalam sehari. Jawa Timur mencatat jumlah terbanyak dengan 409 kasus baru. Kemudian, DKI Jakarta mencatat 378 kasus baru. Berikutnya, Sulawesi Selatan dengan 180 kasus baru; Jawa Tengah dengan 100 kasus baru, serta Sumatera Utara dengan 87 kasus baru. Baca juga: Jawa Timur: Paling Sedikit Periksa Spesimen, Catat Kasus Covid-19 Tertinggi Data pasien sembuh dan meninggal Dalam periode yang sama, diketahui ada penambahan 1.190 pasien Covid-19 yang sembuh. Para pasien itu dinyatakan sembuh setelah pemeriksaan dengan metode polymerase chain reaction (PCR) memperlihatkan hasil negatif virus corona. Dengan demikian, total ada 34.719 pasien Covid-19 yang kini dianggap sembuh dan tak lagi terinfeksi virus corona. 
Kota Depok tercatat terbanyak sementara dengan 177 kasus positif Covid-19. Ada penambahan 13 kasus Corona. Selanjutnya, Kota Bandung dengan 144 kasus, Kabupaten Bogor (68), Kota Bekasi (63), Kota Bogor (60), Kabupaten Bekasi (57), Kota Cimahi (32), Kabupaten Bandung (31), Kabupaten Bandung Barat (25), Kota Sukabumi (23), Kabupaten Subang (14), Kabupaten Karawang (9), Kabupaten Purwakarta (8), Kabupaten Sukabumi (6), Kabupaten Kuningan (5), Kota Tasikmalaya (5), Kabupaten Sumedang (4), Kabupaten Cirebon (3) dan Kabupaten Garut (3), Kabupaten Ciamis (2), Kabupaten Indramayu (2), Kota Banjar (2), Kabupaten Cianjur (1), Kabupaten Majalengka (1), dan Kota Cirebon (1). Secara nasional, data pemerintah pusat mencatat jumlah pasien positif Corona per hari ini mencapai 7.775 kasus. Rinciannya, sebanyak 647 orang meninggal dunia dan sembuh 960 orang. Provinsi DKI Jakarta masih menjadi wilayah penyumbang terbanyak kasus positif Corona dengan 3.517 kasus. Sedangkan, Jawa Barat yang berbatasan wilayah dengan Jakarta berada di urutan kedua. Kasus virus Corona atau Covid-19 hampir merata ditemukan di seluruh kelurahan di Kota Depok. Berdasarkan data yang dirilis di Pusat Informasi Covid-19 Kota Depok per 9 Mei 2020, 59 dari 63 kelurahan di Kota Depok memiliki kasus positif corona. Artinya, ada 4 kelurahan di Kota Depok yang belum memiliki atau terbebas kasus positif corona. Yaitu Kelurahan Leuwinanggung, Kelurahan Pengasinan, Kelurahan Bojong Pondok Terong dan Kelurahan Gandul.

Melihat analisis situasi diatas maka Kelurahan Pengasinan harus melakukan pengawasan ketat di setiap RT agar mampu memutuskan mata rantai penyebaran virus corona atau Covid-19. Kelurahan Pengasinan harus mampu memanfaatkan organisasi pemerintahan yang bagus ini untuk mencegah penularan masif. Pergerakan manusia di tingkat RT/RW bisa dibatasi jika ada kemauan setiap stakeholder.

Organisasi yang juga menjangkau setiap RT dan RW adalah Karang Taruna sedang di level desa dan kelurahan ada berbagai organisasi yang bisa dikerahkan untuk memerangi Covid-19, yakni Karang Taruna, organisasi kemasyarakatan termasuk kepemudaan, dan sebagainya. Upaya pencegahan sebaran Covid-19 melalui rapid test atau pemeriksaan cepat dan massal serta penelurusan kontak yang cepat tidak akan berhasil apabila tidak melibatkan berbagai elemen masyarakat.

Sementara itu berdasarkan pengamatan gerakan dari bawah sebagai sebuah kesadaran masyarakat mencegah penularan Covid-19 terlihat pada kegiatan warga di banyak kompleks perumahan. Mereka melakukan penyemprotan disinfektan secara mandiri di lingkungannya. Sejumlah kompleks perumahan terutama di Jabodetabek, sebagai episentrum penyebaran Covid-19, memasang alat semprot di pintu gerbang perumahan. Setiap warga dan tamu yang datang wajib masuk dalam ruang atau pintu semprot. Sebagian lagi menggunakan alat semprot manual. Di sisi lain, info mengenai status orang dalam pemantauan (ODP) cepat tersampaikan ke gugus tugas kota maupun kabupaten dari RT dan RW.

Selama ini Karang Taruna bisa memberikan kontribusinya dalam berbagai upaya mengelola dan menangani masalah sosial. Seperti bencana alam, bencana sosial, dan berbagai dinamika baik lokal maupun nasional. Karang Taruna sudah teruji dengan berbagai situasi dan tantangan. Jadi dalam menghadapi pandemi virus Corona, Karang Taruna bisa mengambil peran positif dan mengambil peran berarti. Pilar sosial dianggap mengenal daerah masing-masing adalah kunci utama dalam penanganan COVID 19. Di lain pihak, sebagian dari Karang Taruna tersebut merupakan pendamping untuk penerima manfaat.

Karang Taruna bisa menyosialisasikan berbagai kebijakan pemerintah, baik di pusat maupun di daerah, terkait percepatan pemberantasan virus Corona masyarakat atau penerima manfaat yang mereka dampingi. Karang Taruna juga bisa menggugah kesadaran masyarakat agar, misalnya, taat pada anjuran pemerintah untuk tetap tinggal di rumah. Tentu saja, dalam melaksanakan himbuan pemerintah pihak karang taruna juga perlu kehati-hatian, dan 
memperhatikan keselamatan dan kesehatan diri dan lingkungan. Untuk sosialisasi langkahlangkah pencegahan penyebaran virus, jangan lupakan ketentuan yang sudah digariskan.

Dengan keberadaan karang taruna seperti disampaikan diatas maka pemuda dalam hal ini karang taruna Kelurahan Pengasinan harus dapat dilibatkan dalam upaya penanganan COVID 19 dengan lingkungan yang paling kecil yaitu Kelurahan Pengasinan RW 11. Tujuan dasar pada saat terbentuknya Karang Taruna RW 11 (kami beberapa Dosen Universitas Pamulang yang membantu pembentukan Karang Taruna RW 11, pada saat Pengabdian Kepada Masyarakat beberapa waktu lalu) agar Karang Taruna sebagai generasi muda dapat bermanfaat dan membantu semua Program Pemerintah untuk masyarakat sekitar.

Berdasarkan latar belakang masalah tersebut maka tim Pengabdian Kepada Masyarakat melakukan penyuluhan dengan judul "Peran Karang Taruna Dalam Sosialisasi Pencegahan Dan Penanggulangan Serta Penularan Covid-19 Di Lingku-Ngan Rw 011 Kelurahan Penga-Sinan, Kota Depok".

\section{B. METODE PELAKSANAAN KEGIATAN}

Metode yang digunakan pada Pengabdian Kepada Masyarakat ini berupa ekspositori yaitu penyampaian materi secara verbal dan inquiry yaitu pembelajaran yang menekankan pada proses berpikir kreatif kritis dan analitis terkait optimalisasi organisasi terutama dalam bidang keuangan dan bisnis, yaitu meliputi :

1. Pendampingan.

Pada kegiatan ini dilakukan brain storming untuk membuka pemahaman menganai bahaya Covid-19

2. Penyuluhan

Aspek yang akan dikaji dalam kegiatan penyuluhan ini adalah faktor pembinaan dan pencegahan penyebaran Covid-19

3. Praktek

Pada kegiatan ini diajarkan kegiatan dalam upaya pencegahan Covid-19, yaitu cuci tangan secara rutin, menjaga jarak, menggunakan masker, tidak menyentuh mata, hidung dan mulut, jangan keluar rumah jika kurang sehat, dan jika muncul gejala Covid-19, segera cari bantuan medis.

4. Pelatihan Kegiatan ini terkait melaksanakan protokol pencegahan penyebaran Covid-19:

\section{HASIL DAN PEMBAHASAN}

Pelaksanaan pengabdian kepada masyarakat yang dilakukan oleh lima dosen Program Studi Manajemen Universitas Pamulang di RW 011, Kelurahan Pengasinan, Kota Depok, Provinsi Jawa Barat ini dalam rangka pendampingan peran Karang Taruna dalam sosialisasi pencegahan dan penanggulangan Penularan COVID 19 di lingkungan RW 011 Kelurahan Pengasinan dilaksanakan pada tanggal 2 Maret s/d 10 Juli 2020 ini dengan melakukan koordinasi program dengan stakeholder sekitar yang melibatkan Pengurus RW 011. Bapak Edy Siswanto selaku Ketua RW 011 berserta jajarannya sangat mendukung pelaksanaan pengabdian kepada masyarakat ini dengan target dan luaran yang dihasilkan adalah program. sosialisasi penataan pencegahan dan penanggulangan penularan Covid-19.

Hasil keluaran program sosialisasi ini antara lain adalah:

1. Sosialisasi tentang bahaya Covid-19 kepada warga di lingkungan Rw. 011

2. Pelatihan dan Pembinaan kepada pemuda Karang Taruna RW. 011 untuk ikut serta terlibat secara nyata dalam rangka membantu menyelesaikan permasalahan yang terkait dengan Covid-19.

3. Memberikan bantuan 60 paket sembako kepada warga yang terdampak Covid-19 
4. Mempublikasikan kondisi lingkungan RW.011 dan kegiatan pengabdian kepada masyarakat di stasiun TV Pemerintah dalam hal ini TVRI Jakarta Banten dalam program Jakarta Hari Ini.

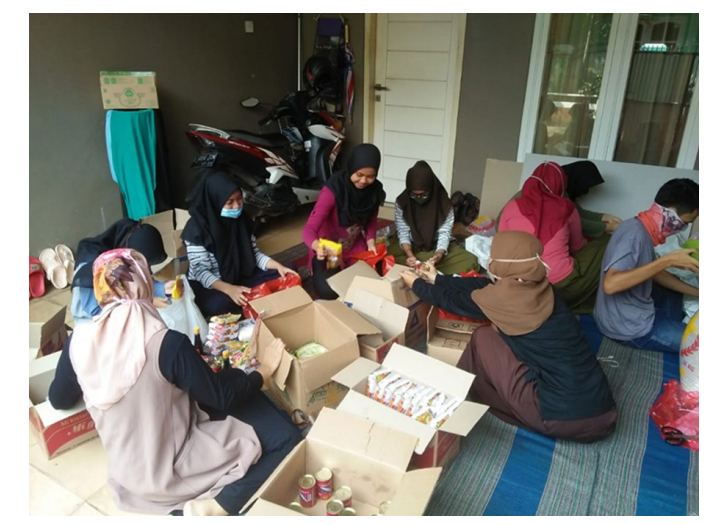

\section{Gambar 1. Kegiatan karang taruna RW.11}

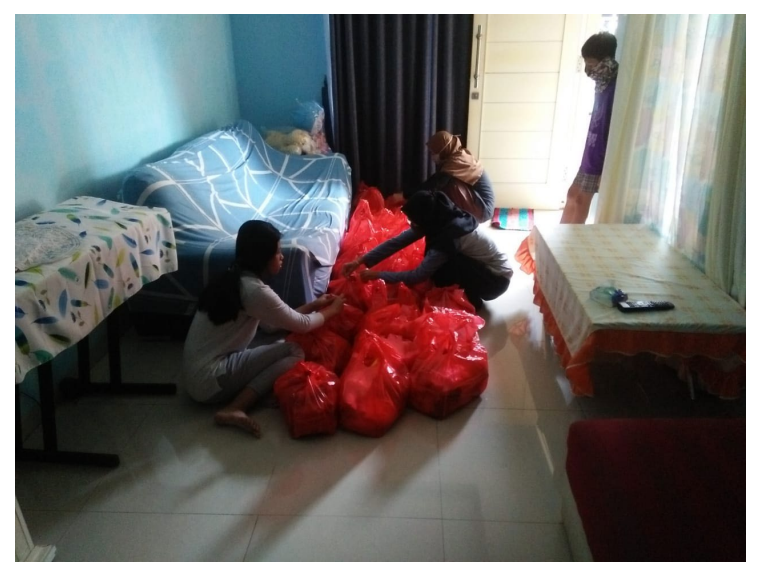

Gambar 2. Persiapan Pembagian Sembako

\section{KESIMPULAN DAN SARAN}

\section{Simpulan}

1. Covid-19 melanda banyak Negara di dunia termasuk Indonesia. Wabah Covid-19 tidak hanya merupakan masalah nasional dalam suatu Negara, tapi sudah merupakan masalah global. Covid-19 berawal muncul dari daerah Wuhan Cina. Penyebaran Covid -19 yang begitu cepat dan mematikan, penularannya melalui kontak fisik ditularkan melalui mulut, mata dan hidung. Covid-19 berdampak kepada kehidupan sosial dan melemahnya ekonomi masyarakat. Untuk mencegah penyebaran wabah Covid- 19 diperlukan kerja sama pemerintah, masyarakat, tokoh agama untuk saling bantu membatu, bahu membahu dan mengingatkan satu sama lainnya bersama melawan Covid-19.

2. Peran masyarakat khususnya pemuda yang tergabung dalam wadah karang taruna memiliki peran penting dalam membantu meminimalisasi dampak Covid-19.

3. Sterilisasi wilayah perlu dilakukan dengan penyemprotan disinfektan di seluruh area lingkungan RW. 011 yang dilakukan secara serentak, hal ini untuk memutus mata rantai penyebaran virus corona. 


\section{Saran}

1. Perlu dilakukan Sosialisasi dalam bentuk himbauan melalui spanduk, group WA dan juga pengeras suara musholah kepada warga agar semua warga dapat membatasi aktifitasnya di luar rumah untuk mencegah terjadinya penyebaran virus corona.

2. Perlu melakukan pengawasan terhadap beberapa warga yang terindikasi terjangkit virus corona baik ODP maupun PDP dan melakukan tindakan-tindakan yang diperlukan dalam rangka pencegahan dan penyebaran wabah covid-19.

3. Selain itu perlu melakukan pendataan terhadap warga masyarakat di lingkungan RW.011 yang berdampak secara ekonomi akibat wabah virus corona ini. Hal ini di lakukan untuk memastikan bahwa tidak ada warga di lingkungan RW.011 yang mengalami kekurangan pangan.

4. Pelibatan peran serta ibu - ibu dan juga karang taruna baik untuk melakukan pendataan dan pengumpulan donasi dari warga yang memiliki kelebihan rezeki serta mendistribusikannya kepada warga terdampak yang sangat membutuhkan

\section{Ucapan Terima Kasih}

Kami mengucapkan terimakasih kepada para pihak yang terlibat dalam kegiatan PKM ini, sehingga PKM dapat terlaksana dengan baik.

\section{DAFTAR PUSTAKA}

Dumilah, R., Sunarto A., Ahyani, Solihin, D., Maulida H. (2020). Pelatihan Pemanfaatan Media Sosial Untuk Promosi Usaha Atau Bisnis Bagi Siswa. DEDIKASI PKM. Vol. 1. No. 1.

Handayani, Annisa Yulia. (2015) Persepsi Pemuda terhadap Peranan Karang Taruna dalam Penanganan Masalah Sosial. Jurnal penyuluhan Vol.11 No.1

Solihin, D. (2020), Mulai Usaha di Masa Pandemi? Ini 'Analisis SWOT' Strateginya. rakyatmerdekanews.com.

Suharta, RB, (2009). Pengembangan Organisasi Kepemudaan. Jurusan Pendidikan Luar Sekolah, Fakultas Ilmu Pendidikan Universitas Negeri Yogyakarta. Yogyakarta

Peraturan menteri sosial Republik Indonesia NO: 77/HUK/2010. 2010. Pedoman Dasar Karang Taruna. Jakarta: Kemensos RI

Jawa Pos. (2016). 5 Wilayah Rawan Narkoba. https://www.pressreader.com/indonesia/jawapos/20160106/282720520945251. Diakses 3 Oktober 2017

Permensos 83/HUK/2005 tentang Pedoman Dasar Karang Taruna UU Nomor 40 Th 2009 tentang Kepemudaan Permensos 77 Th 2005 tentang Pedoman Dasar Karang Tarun 